\title{
New Urban Regeneration for the City of Amman Using Sustainable Urban Design Principles: Al-Abdali Area As a Case Study
}

\author{
Rami Khaled Al Shawabkeh \\ ${ }^{1}$ Research Scholar, Department of Architecture, Al-Albayt University, Mafraq 25113, Jordan.
}

\begin{abstract}
This research tries to define and explore the application of LEED-ND approach as a tool to evaluate the extent of sustainable urban design principles (SUDP) application for regenerating new urban developments in the Amman Master Plan, Jordan. Sustainability; the use of resource and materials as well as the delivery of resource efficient spaces, products and services, are an increasingly important factor in the evolution of urban environments. Urban regeneration is an urban development comprising a small to medium-sized district with a broad range of housing and planned commercial, and recreational facilities. This is to address community demands due to increasing population and migratory trends into cities. The need to undertake this research in Amman is that Amman remains a little studied city in spite of a growing body of work on Arab urbanism. It has therefore become necessary to address the issues taking advantage of the opportunity to integrate sustainable development solutions to guide future development. The primary research aim is to explore the applicability of defined SUDP in the Amman context, to investigate criteria to regenerate sustainable urban development centers in Amman. Using existing literature, this paper will review global SUDP as it applies to the Amman context and highlight the extent of SUDP application for regenerating new urban developments in the selected case study area. Context-derived data and statistics analysed together with the Amman Master Plan will then be used to explore the guidelines for the application of sustainable urban design principles using LEED-ND approach, by exploring the indicators affecting the effective delivery of the new urban developments in the specified area. The paper concludes with a series of multi-faceted recommendations based on lessons learnt from Al-Abdali area as a case study, therefore it contributes to develop the Amman master plan through regenerating new urban developed areas.
\end{abstract}

Keywords: LEED-ND, Sustainable Urban Design Principles (SUDP), Urban Development, Amman, Al-Abdali

\section{INTRODUCTION}

Sustainable urban design, based on an environment-friendly practice, is a prevalent concept in architectural and urban thinking. Miller [32] argued that understanding sustainable urban design requires an examination of the relationship between urban design and sustainability. It focuses on the relationship between buildings and the environment considering the importance of meeting present needs without losing sight of the right of future generations.
This research was built on previous work for the development of the 2015 Abdali Master Plan. sustainable high density mixed use (HDMU) development in the Abdali area conceived as part of master planned areas in a new one area of activity for Amman and for Jordan. This area was built on the application of sustainable urban design principles. At the commencement of this research, it was not known how these principles were implemented in the Abdali context or what criteria/indicators could be applied to enable this to happen. Accordingly, there was a need to research and identify a framework addresses the issues taking advantage of the opportunity to integrate sustainable development solutions to guide future development. The research aims to explore the applicability of defined sustainable urban design principles in the Amman context using sustainable urban design approaches such as; LEED-ND through discussing and exploring key aspects related to sustainable urban design indicators, to investigate criteria to regenerate sustainable urban developments in Amman. It proposes a set of multi recommendations that can constitute a framework for providing the guidelines for implementing sustainable urban design principles in a rapidly growing city.

\section{Research problem}

The primary research problem defined with examining the Abdali area design, and highlighting the use of sustainable urban design principles and the extent of the success of designer ideas in applying them. This paper seeks to explore whether the Abdali area in Amman achieves the main purpose that is designed for. This could be achieved through testing sustainable urban design approaches such as; LEEDND using its indicators.

\section{Methodology}

The research used the testing-out approach in depending on a mixed method to achieve the main objectives at two stages. The first, it tested the quantitative indicators identified in the literature review in the context of the Abdali master plan in Amman by the content analysis. this was achieved by using study visits, direct observation unstructured interviews as a qualitative method, which were used to understand the main features of the Abdali Master Plan. The second, it was used to test variables defined as: qualitative indicators and check quantitative indicators by using a questionnaire survey as a quantitative method, which increases the credibility of research results. The survey analysis was done by developing and distributing questionnaire to a wide range of stakeholders in the Abdali master plan in Amman. The study analyzed all collected data to get the research findings achieving the main aim of this research. 
The testing-out approach is the process of using quantitative methods and qualitative methods to evaluate hypotheses, theories and indicators [47] [31]. These methods involve the evaluation of indicators by numeric facts, content analysis and stakeholders. Nevertheless, the testing-out approach is limited as a means of identifying and quantifying the criteria on which hypotheses are based [38] [30]. This is because it depends on concentrations tested, its statistical power is influenced by variability and its inability to calculate confidence intervals [28] [43]. Therefore, this study also utilised two methods such as; qualitative and quantitative to support the results of the testing-out approach.

\section{LITERATURE REVIEW}

The research is predicated on the role LEED-ND approach play in identifying the extent of sustainable urban design principles application for regenerating new urban developments in Amman using the Abdali area. Three key concepts relevant to this research are therefore examined in this section. The first is that of sustainable urban design principles, the second is that of the LEED-ND indicators and the third is that of the Abdali master plan in the city of Amman.

\section{Sustainable urban design principles}

Thomas and Fordham [44] describe sustainable urban design as "the sustainability in the physical aspects of an urban environment that include the buildings and their engineering systems, transport systems, green and open spaces, energy, water and waste systems". It can also incorporate architecture, urban planning, landscape architecture, and civil engineering [34] [16].

The measurement and the application of sustainable urban development principles in the community require the implementation of appropriate sustainability indicators [12]. For the purposes of this research, there should be an understanding of what the sustainable urban design principles are that can be used to constitute an essential nucleus to achieve sustainable urban design goals in urban areas. The emphasis is, therefore, on in-city development and an understanding of the principles of urban sustainability to deliver it. These principles are discussed .

For the purpose of this research, these principles are defined as principles that can achieve sustainable urban design goals covering a range of social, environmental, economic and governance issues. The Greater Amman Municipality used a set of principles of sustainable urban design that addresses the above issues while taking advantage of the opportunity to integrate sustainable development solutions to guide future growth and development [18]. This vision was put together proposed densification of areas in the city. These principles are represented in; (1) integrate ecologically sensitive urban design guidelines, (2) culture and heritage promotion, (3) green city principles, (4) effective governance and service delivery, and (5) public spaces and social inclusion [19] [35]. Up to now, this section of the literature review discussed the principles of urban sustainability, which should be pursued in a manner that maximizes the efficient utilization of energy resources, and minimizes or eliminates local and global environmental degradation.
After understanding how sustainable urban design principles constitute an essential nucleus to achieve sustainable urban design practices in urban areas, it was found that the application of these principles needs a set of indicators to be applied effectively. The next section outlines the process by which a multitude of suitable urban sustainability indicators were reconciled before a final list was defined and used for the "testing purpose" of this study.

\section{Urban sustainability indicators}

The use of sustainability indicators helps decision makers to be better informed about the impact of future development in line with an understanding of past experiences [37] [33] [3]. The use of indicators also offers the opportunity to improve the knowledge and practice of sustainability by providing a basis of analysis and decision making [11] [9] [7] [33] [40]. Therefore, measuring sustainability indicators provides environmental, social and economic information which can be seen as significant tool for communicating information to decision makers and also to the public in a straightforward and easy-to-follow manner [22] [23]. In broad terms, indicators can be used to evaluate the performance of projects, buildings, communities, and countries [48].

In order to achieve the stated aims of the study, the literature review on indicators highlights the Council of the European Union Sustainable Development Strategy (European Commission, Eurostat, [15], international urban sustainability indicators CSD, UN, [46], Shen et al., [42], LEED ND [25], BREEAM Communities [10], GORD/GSAS ND [21], Green Star [20], ESTIDAMA [13], SuBE Tool, and other scientific papers and authors like Serge Salat, [39]. From the thorough examination of sustainability indicators shown in the Appendix 1, it is noted that some of those indicators reviewed were excluded from the analysis undertaken as part of the study. A subset of the indicators (including the United Nations Sustainable Development Indicators, Eurostat Sustainable Development Indicators, BREEAM Communities, the Estidama-Pearl Community Rating System (PCRS) and GORD-GSAS were excluded because of the emphasis they placed on broader aspects of sustainable communities at the expense of specific measures around sustainable urban design practices such as: proportion of population living below national poverty line, number of sworn police officers per 100,000 population and nutritional aspects of child health status and risks. Additionally, GSAS includes indicators to address social and environmental issues without taking into account the most important economic and governance issues related to sustainable urban design. The decision was taken to exclude the Green Star system because, as Australia's only national rating system, it placed undue emphasis on local conditions for sustainable buildings and sustainable community development in Australia. It cannot, therefore, be used by this research to test the indicators related to sustainable urban design specifically in Amman. Morever, SuBE Tool was also excluded because it addresses generally sustainable urban development issues at neighbourhood level.

Accordingly, this thesis has not adopted these indicators but shifted its focus to those that are applicable to sustainable urban design at neighbourhood level. One such list is the 
LEED-ND approach which will be examined.

\section{Leadership in Energy and Environmental Design for Neighbourhood Development (LEED-ND)}

LEED is a certification programme developed by U.S. Green Building Council at the end of the 1990s [36] [26]. The motivation to create this system was the demand for an assessment tool that can measure and compare the sustainability of the buildings [27]. The Natural Resources Defence Council (NRDC), the U.S. Green Building Council (USGBC) and the Congress for the New Urbanism (CNU) have jointly established a measurement system for evaluating and rewarding neighbourhood planning and development practices according to the framework of the LEED Green Building Rating System [25]. The LEED-ND approach has three basic indicators: smart location and linkage, neighbourhood pattern and design, and green infrastructure and buildings [4]. It also includes two additional categories: innovation and design process and regional [36] [25] [41].

From the literature, it is obvious that LEED-ND attempts to enable its use in and suitability for other countries but, as yet, it has been implemented outside the United States successfully. It can, therefore, be considered an approach that fits another local government policies although existing differences between them across districts, which affect local development patterns [26] [27] [5]. Moreover, this approach includes indicators that address environmental design with taking into account the most important social, economic issues as related to sustainable urban design. Additionally, it applies to new land development projects or redevelopment projects containing residential uses, non-residential uses, or a mix. This therefore accords with the selected case in this study, which was designed based on the above identified sustainable urban design principles by the Greater Amman Municipality.

Table 1 shows the LEED-ND approach which includes the urban sustainability indicators and their measurements tested at the neighborhood level. Finally, this approach consists of four categorizations to measure these indicators at the Abdali neighborhood level. These categories are represented in; Basic Certification (40 - 49), Silver Certification (50 - 59), Gold Certification (60 - 79) and Platinum Certification (80 110).

Table 1: LEED-ND Model; (Sources: LEED, 2009a). Modified by the researcher

\begin{tabular}{|l|cl|}
\hline Indicators & Measurements \\
\hline Smart Location and Linkage & 1. & preferred Locations \\
& 2. & Brown fields Redevelopment \\
& 3. & Locations with Reduced Automobile \\
& 4. & Dependence \\
& Bicycle Network and Storage & Housing and Jobs Proximity \\
& 6. & Steep Slope Protection \\
& 7. & Site Design for Habitat or Wetland and Water \\
& 8. & Body Conservation \\
& Restoration of Habitat or Wetlands and Water & Bodies \\
& 9. & Long-Term Conservation Management of \\
& & Habitat or Wetlands and Water Bodies \\
\hline
\end{tabular}

\begin{tabular}{|l|ll|}
\hline Neighborhood Pattern and & 1. & Walk able Streets \\
Design & 2. & Compact Development \\
& 3. & Mixed-Use Neighborhood Centers \\
& 4. & Mixed-Income Diverse Communities \\
5. & Reduced Parking Footprint \\
& 6. & Street Network \\
7. & Transit Facilities \\
& 8. & Transportation Demand Management \\
& 9. & Access to Civic and Public Space \\
& 10. & Access to Recreation Facilities \\
& 11. & Visit ability and Universal Design \\
& 12. & Community Outreach and Involvement \\
& 13. & Local Food Production \\
& 14. & Tree-Lined and Shaded Streets \\
& 15. & Neighborhood Schools \\
\hline Green Infrastructure and & 1. & Certified Green Buildings \\
Buildings & 2. & Building Energy Efficiency \\
& 3. & Building Water Efficiency \\
& 4. & Water-Efficient Landscaping \\
& 5. & Existing Building Reuse \\
& 6. & Historic Resource Preservation and Adaptive \\
& 7. & Use \\
& & Minimized Site Disturbance in Design and \\
& 8. & Construction \\
& 9. & Storm water Management \\
& 10. & Solar Orland Reduction \\
& 11. & On-Site Renewable Energy Sources \\
& 12. & District Heating and Cooling \\
& 13. & Infrastructure Energy Efficiency \\
& 14. & Wastewater Management \\
& 15. & Recycled Content in Infrastructure \\
& 16. & Solid Waste Management Infrastructure \\
& 17. & Light Pollution Reduction \\
\hline Regional Priority & 1. & Innovation and Exemplary Performance \\
& 2. & LEED Accredited Professional \\
\hline 1. & Regional Priority \\
\hline & & \\
& & \\
& &
\end{tabular}

This section identified the indicators related to the process of application of sustainable urban design principles in the case of Abdali area that can be measured at the neighbourhood level. Therefore, the next section presents the case of Abdali area in Amman for testing the identified indicators for providing guidelines can be used effectively in the context of Amman.

\section{The Abdali Master Plan as a case study}

Abdali district is described as the new downtown of Amman, which considers the largest mixed-use development project ever constructed in the heart of the Jordanian capital (Abdali, 2004). Project areas is $384,000 \mathrm{~m}^{2}$ of land where the project comprises of a total built-up area (BUA) of over 2 million $\mathrm{m}^{2}$ consisting of residential apartments, commercial offices, hotels and serviced apartments, retail outlets as well as medical and entertainment facilities. It also includes seven main entrances serving all of project [24].

The project aimed to collect tradition and originality of Jordan along with higher modernity and progress of civilization standards, be new urban sustainable town, work to provide a safe environment, healthy and vibrant. Abdali district is strategically located in the centre of major commercial, financial, public, touristic and medical institutions in the heart of Amman as shown in the Figure 1.

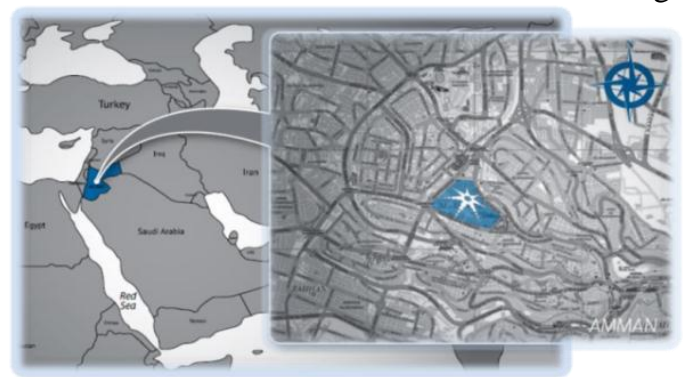

Figure 1: The Hashemite Kingdom of Jordan: Abdali location, (Sources: GAM, 2010). Modified by the researcher 
At the heart of the Middle East and providing easy access to North Africa, the GCC and the Levant, Jordan has a lot to offer [24] [2]. Besides its strategic location, the Hashemite Kingdom enjoys a progressive free-market economy and political stability, making it a preferred destination for business leaders, investors and visitors alike [49]. With the new downtown, Abdali, rising in the capital and other largescale projects taking place in Jordan as a whole, the country's offerings are exponentially advancing toward becoming a safe and prosperous haven for all businesses (Figure. 1). Therefore, this case was chosen due to it is situated in the heart of Amman, Abdali is the first area in Amman that is being developed under the new local mixeduse planning codes, which represents the exceptional synergy of residential, commercial, hospitality, medical and retail outlets in one vibrant and prestigious address. Generally, the Abdali district creates a modern downtown previously missing from Amman, which will cater to business and lifestyle requirements, as well as create additional employment opportunities and provoking an unprecedented influx of investments from Jordan and the region.

It is noted that the first phase of Abdali project lies on 251,000 sqm of land and contains 33 separate mid-rise building and tower projects owned which were developed by a multitude of local and international investors (Figure. 2). The second phase lies on 133,000 sqm adjacent to the first phase. Table 2 also offers the identified built-up areas to each function of the main zoning at the two phases. The infrastructure for the two phases mirrors that the Abdali district will be the new downtown reinforced with the concepts of a smart city.

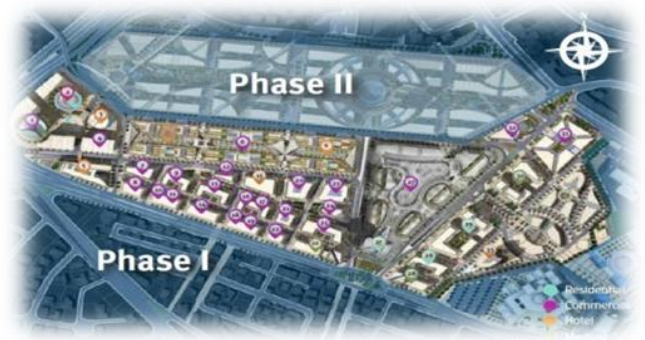

Figure 2: Abdali plan phases, (Sources: GAM, 2017). Modified by the researcher

Table 2: The data extracted from the content analysis of Abdali area (Sources: the researcher)

\begin{tabular}{|l|l|l|ll|}
\hline & Phase 1 & Phase 2 & \multicolumn{2}{|l|}{ Total Area } \\
\hline Built-up area & $1,030,000 \mathrm{~m}^{2}$ & $970,000 \mathrm{~m}^{2}$ & 2 million $\mathrm{m}^{2}$ & \\
\hline Residential & $261,000=25 \%$ & $708,000=72 \%$ & $\begin{array}{l}969,000 \quad \\
49 \%\end{array}$ & $=$ \\
\hline Commercial & $547,000=53 \%$ & $186,000=20 \%$ & $733,000 \quad 36 \%$ & $=$ \\
\hline Medical & $73,000=08 \%$ & --------------- & $73,000=4 \%$ \\
\hline Hotel & $149,000=14 \%$ & $75,000=08 \%$ & $224,000 \quad$ & $11 \%$ \\
& & & & \\
\hline
\end{tabular}

\section{Data analysis}

The purpose of this section of the research is to test the indicators identified as part of the literature review at the neighbourhood level, in the case of Al-abdali area in Amman.

From the literature review, urban sustainability indicators were classified as smart location and linkage, neighbourhood pattern and design, green infrastructure and buildings, innovation and design process and regional priority as shown in Table 2. The following sections present the findings in the appointed case study area.

\section{Indicator 1: Smart Location and Linkage Measure 1.1: Preferred Locations}

This measure refers to the development on a site that is highly accessible and connected to other nearby development. This project was developed within existing city to reduce adverse public and environmental health effects associated with sprawl. Accessibility is achieved from 5 streets by 7 Main entrances and 9 sub- entrances as shown in Figure. 3

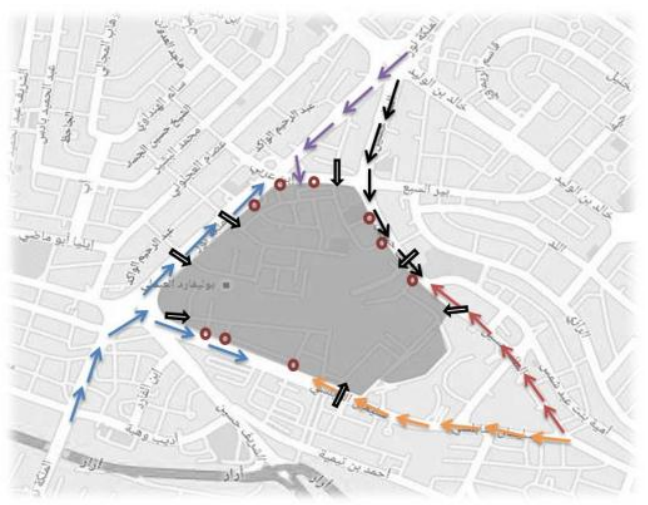

Figure 3: Al-abdali area accessibility, (Sources: Google, 2017). Modified by the researcher

\section{Measure 1.2: Brownfield Redevelopment}

This measure refers to the remediation of a contaminated site. Al-abdali project is considered to be a prime urban location which is appropriate for development. This was because of Avoiding the development of inappropriate sites and reducing the environmental impact from the location of this area on the site, thereby reducing pressure on undeveloped land.

\section{Measure 1.3: Locations with Reduced Automobile Dependence}

This measure refers to the development in an area that is well-served by transit or has a low average driving rate. It is noted that this project location has multimodal transportation choices as shown in Figure. 4.
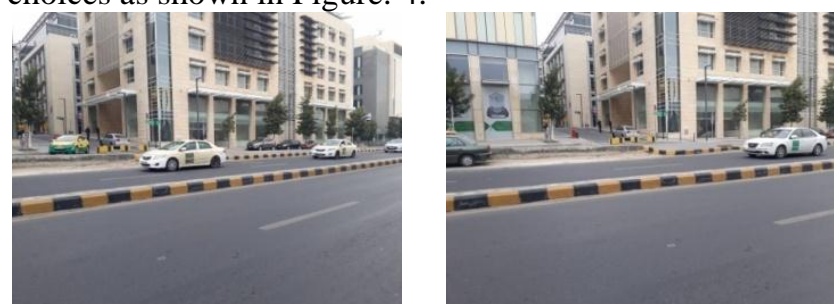

Figure 5: multimodal transportation choices in Abdali area, (Sources: the researcher, 2017).

Measure 1.4: Bicycle Network and Storage

This measure refers to locate along a bicycle network and 
provide bicycle storage and parking. Al-abdali project promoted bicycling and transportation efficiency, including reduced vehicle miles traveled (VMT). Figure. 5 shows that this project provided an existing bicycle network of at least 5 continuous miles in length is within 1/4-mile bicycling distance of the project boundary. Moreover, the project secures an enclosed bicycle storage areas, which are locked and easily accessible to residents and workers, in addition to informational signage on using the storage facilities as shown in Figure. 6.

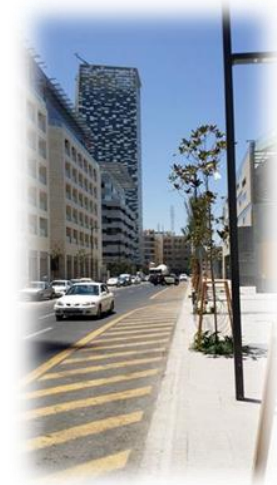

Figure 5: Bicycle's baths the researcher, 2017). in Abdali area, (Sources:

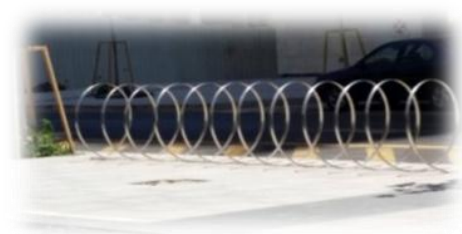

Figure 6: Bicycle's parking in Abdali area, Sources: the researcher, 2017).

\section{Measure 1.5: Housing and Jobs Proximity}

This measure refers to locate jobs and housing, particularly affordable housing, nearby each other. It is noted that this project provided affordable residential component, in addition to encouraging balanced communities with a diversity of uses and employment opportunities (Figure. 7 and 8).

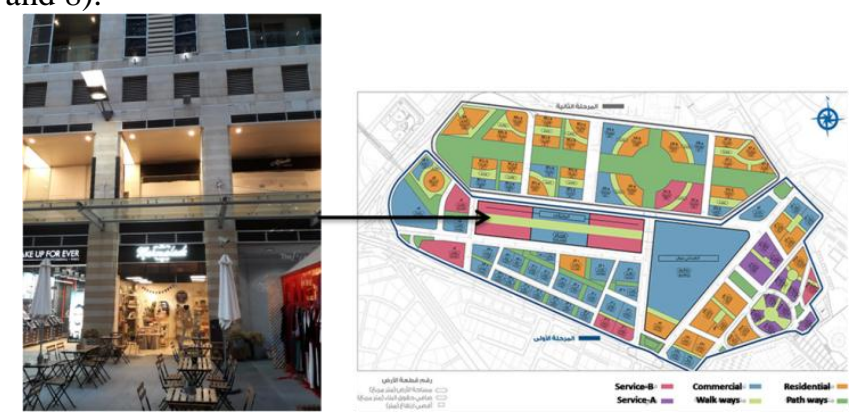

Figure 7: Mixed uses in the Al-abdali area, (Sources: the researcher, 2017). Figure 8: Land uses in the Al-abdali area, (Sources: GAM, 2017).

Modified by the researcher

\section{Measure 1.6: Steep Slope Protection}

This measure refers to the protection of steep slopes from development.

N/A

Measure 1.7: Site Design for Habitat or Wetland and Water Body Conservation

This measure refers to the conservation of pre-existing onsite habitat, wetlands, or water bodies in perpetuity.

N/A
Measure 1.8: Restoration of Habitat or Wetlands and Water Bodies

This measure refers to the restoration of degraded on-site habitat, wetlands, or water bodies, and conserve in perpetuity.

N/A

Measure 1.9: Long-Term Conservation Management of Habitat or Wetlands and Water Bodies

This measure refers to the implementation of a long-term management plan for on-site habitat, wetlands, or water bodies.

N/A

\section{Indicator 2: Neighbourhood Pattern and Design Measure 2.1: Walkable Streets}

This measure refers to the improvement of the pedestrian experience at the street level. The Abdali project includes building frontages facing a public spaces, building heights appropriate to street widths with ratio of $1: 3$, continuous sidewalks were at least $2.4 \mathrm{~m}$ wide on retail or mixed-use blocks and at least $1.2 \mathrm{~m}$ wide on all other blocks, and limited garage entries (Figure. 9). In addition, improve the pedestrian experience at the street level by providing: frequent building entries, ground-level windows, on-street parking, elevated ground-floor units, low street speeds, and/or minimal driveway interruptions of sidewalks (Figure. 9). Also there are $60,000 \mathrm{sqm}$ of pedestrian roads, public piazzas and landscaped public parks [2].

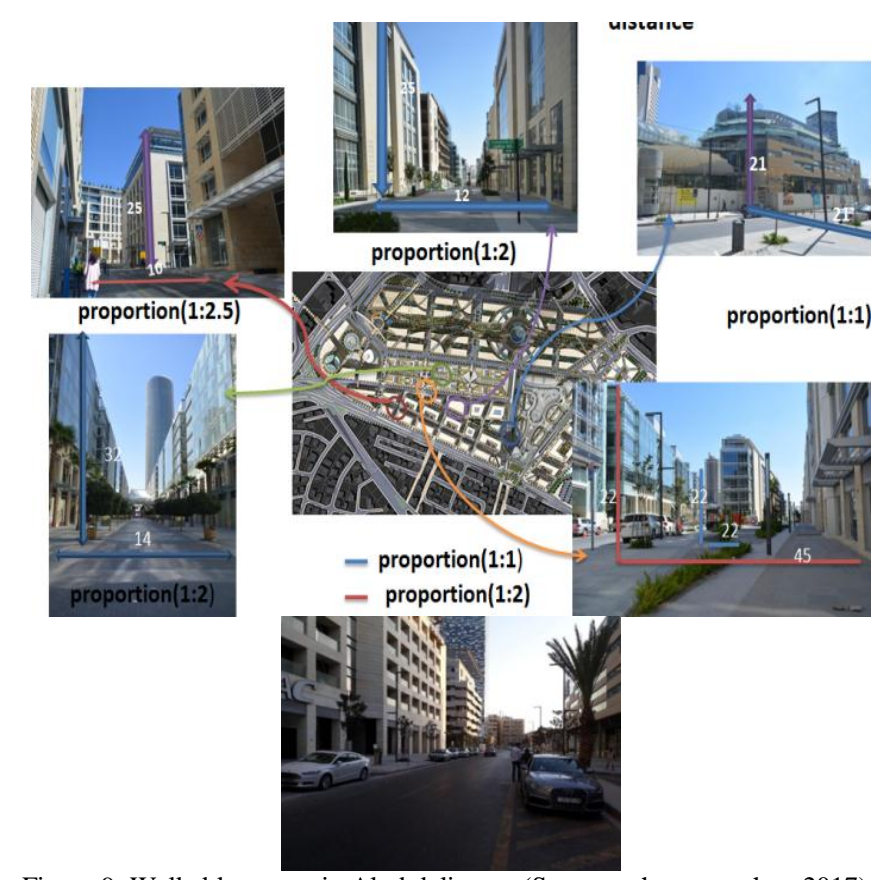

Figure 9: Walkable streets in Al-abdali area, (Sources: the researcher, 2017).

\section{Measure 2.2: Compact Development}

This measure refers to the addition of homes and/or nonresidential space to make efficient use of land. Figure. 10 shows that this area includes 12 or more dwelling units per 1000 M2 for residential uses if residential components were located within the walk distances. It also includes at least 0.80 floor-area ratio (FAR) for non-residential uses with a 
diversity of uses and employment opportunities (Figure. 10). Moreover, this project was designed with internal streets such that its internal connectivity is at least 35 intersections per square kilometre [19].

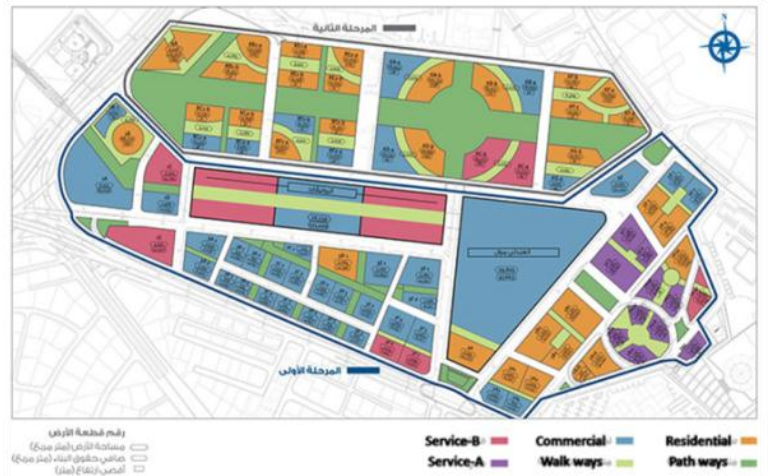

Figure 10: land uses of the Al-abdali area, (Sources: GAM, 2017). Modified by the researcher

\section{Measure 2.3: Mixed-Use Neighbourhood Centres}

This measure refers to providing neighbourhood shops, services, and amenities clustered in neighbourhood centres within walking distance of residents and each other. It is noted that this area includes a wide range of services like libraries, civic buildings, community centres, places of worship, in addition to it contains on recreation facilities like parks, gardens, open spaces and ecological areas are particularly important for urban environments (Figure. 11).
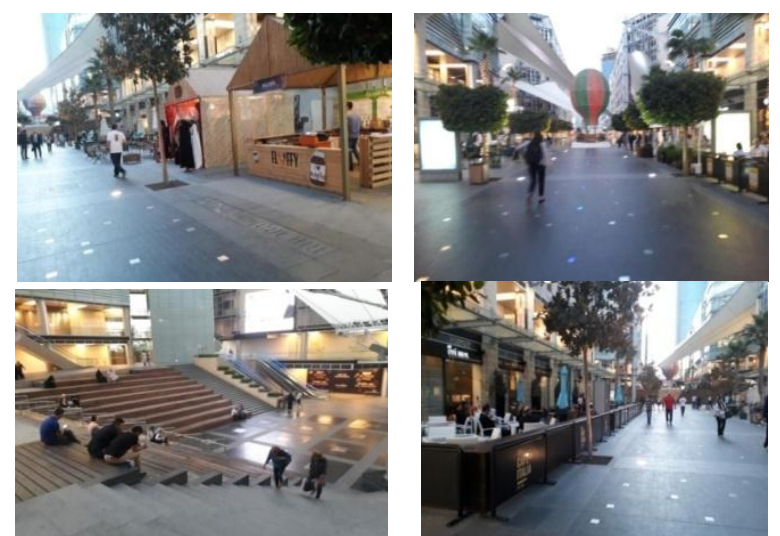

Figure 11: Mixed-use neighbourhood centres in the Abdali area, (Sources: the researcher, 2017).

\section{Measure 2.4: Mixed-Income Diverse Communities}

This measure refers to providing diverse housing types and affordability levels to encourage balanced communities with a diversity of uses and employment opportunities.

N/A

\section{Measure 2.5: Reduced Parking Footprint}

This measure refers to minimizing surface parking lots and discourage them along building frontages. Also provide bicycle and car-share parking. Figure. 12 shows that the project used multiple strategies that can reduce the need for car use like ride sharing, flexible working hours, pedestrian and bicycle promotion, reduced amounts of parking, and minimized surface parking lots. Therefore, this area was serviced by sufficient, secure, and well-placed bicycle and car-share parking for visitors and building occupants.
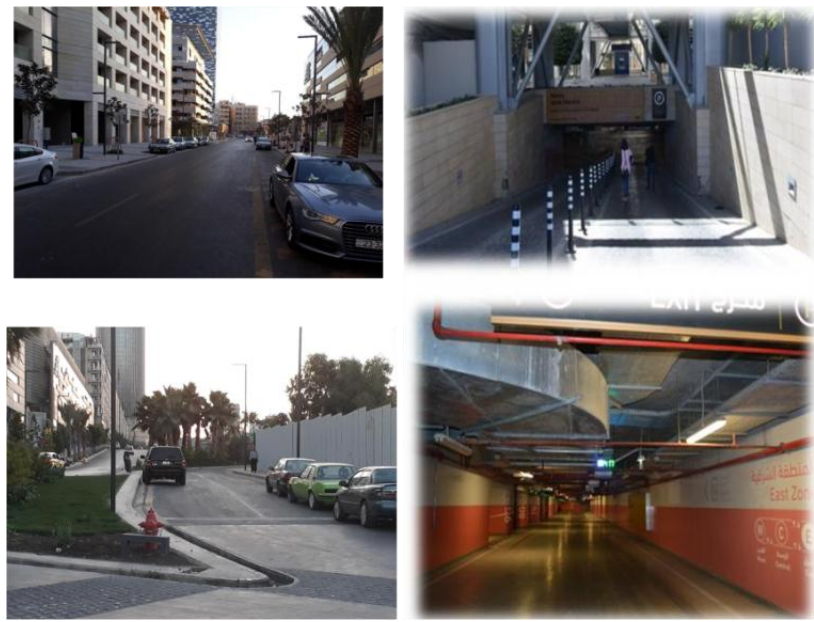

Figure 12: Parking footprint in the Abdali area, (Sources: the researcher, 2017).

\section{Measure 2.6: Street Network}

This measure refers to providing superior connection of streets to each other and adjacent areas, and avoid cul-de sacs. Al-abdali project has high levels of internal connectivity and are well connected to the community at large (Figure. 13). As well as it promoted the use of multimodal transportation which improve public health by encouraging daily physical activity and reducing the negative effects of motor vehicle emissions. Figure 13 offers a set of sidewalks and streets were available for general public use and not gated.

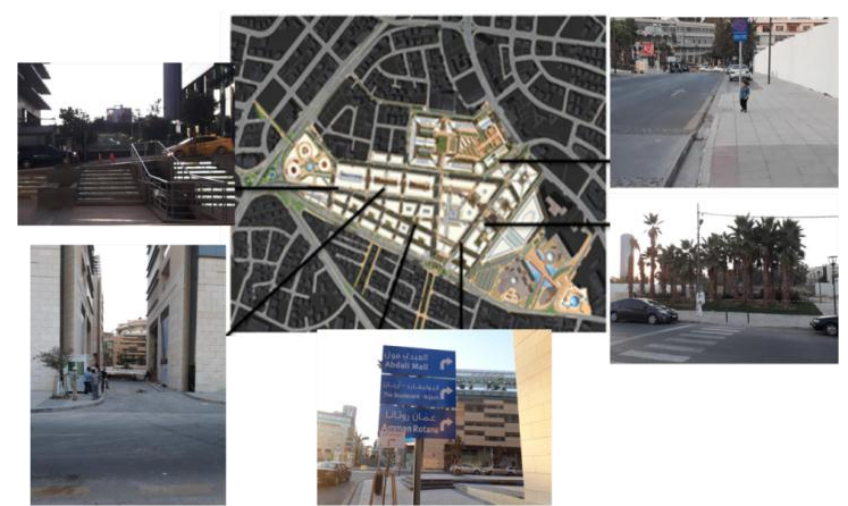

Figure 13: Street network in the Abdali area, (Sources: the researcher, 2017).

\section{Measure 2.7: Transit Facilities}

This measure refers to ensuring shelters, benches, lighting, and information displays at transit stops. Amenities like shelters, benches, lighting, and information displays at transit stops are available within the abdali project for providing fully comfort for the stakeholders (Figure. 14).
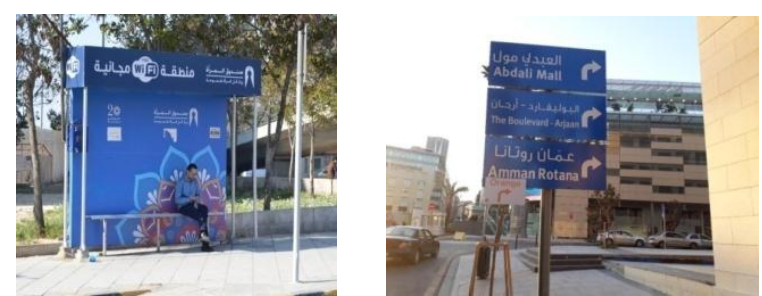

Figure 14: Transit facilities in the Abdali area, (Sources: the researcher, 2017). 


\section{Measure 2.8: Transportation Demand Management}

This measure refers to the encouragement of use of environmentally preferable transportation choices with transit passes, shuttles, vehicle sharing, and/or unbundled parking pricing.

N/A

\section{Measure 2.9: Access to Civic and Public Spaces}

This measure refers to providing squares, parks, and plazas within walking distance of residents and commercial tenants. Figure. 15 shows that a wide range of amenities like civic buildings, open spaces and community centres are constructed by this project to meeting a community's cultural, physical, social, and spiritual needs.
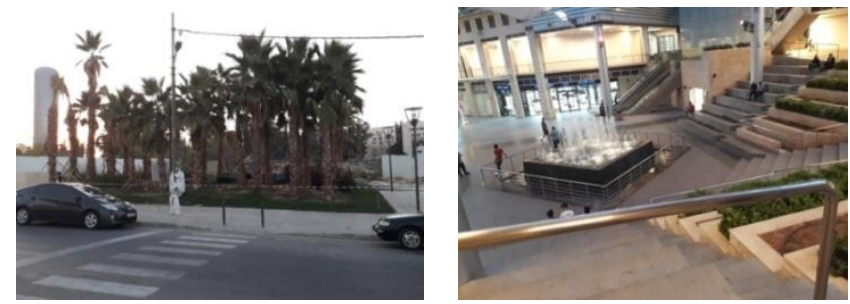

Figure 15: Civic and Public Spaces in the Abdali area, (Sources: the researcher, 2017)

\section{Measure 2.10: Access to Recreation Facilities}

This measure refers to providing indoor or outdoor recreational facilities. Amenities like open spaces, parks, ecological areas, and gardens are particularly designed for urban environment to increase social interaction and more physical activity for community (Figure. 16).
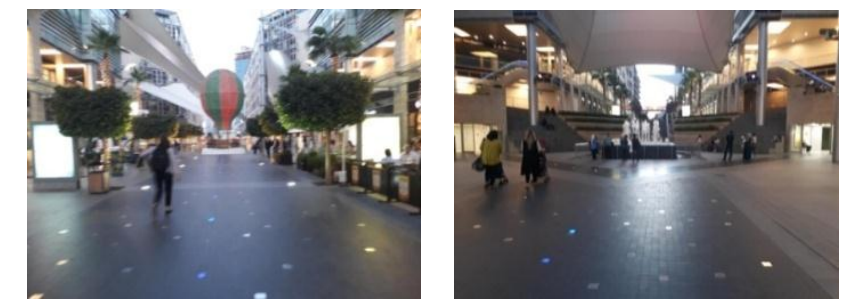

Figure 16: Recreation facilities in the Abdali area, (Sources: the researcher 2017)

\section{Measure 2.11: Visitability and Universal Design}

This measure refers to designing public spaces and dwelling units for all abilities. Figure. 17 shows that the project has considered design of a wide range of public spaces and dwelling units for all society strata, but it focused on the high society strata more than other strata due to expensive prices and costs inside the abdali area [2].
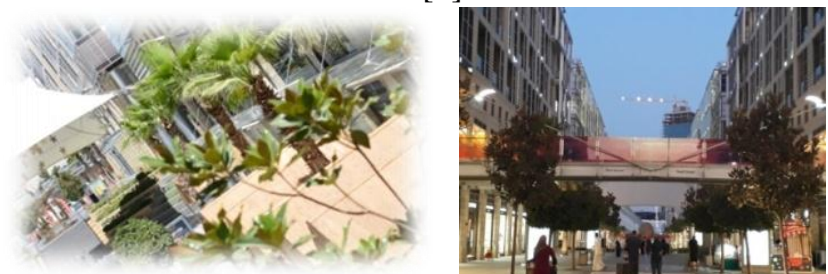

Figure 17: Public spaces in the Abdali area, (Sources: the researcher, 2017).

Measure 2.12: Community Outreach and Involvement

This measure refers to base project designs on community input. There was an effective participation by the local community to hear their views about Greater Amman Municipality's proposals for the abdali project. There also were some meetings with the local community to take account of their views for the new design for the abdali project. However, there are many existing issues between them which have not yet been resolved. These problems arose because of the unsuitability of a set of regulations and laws which govern land use [19].

\section{Measure 2.13: Local Food Production}

Provide access to gardening space, local produce, or a farmer's market.

N/A

Measure 2.14: Tree-Lined and Shaded Streets

This measure refers to designing line and shade streets with trees. It is noted that the project uses two options to achieve this criteria. The first is tree-lined streets that were designed and built to provide street trees on both sides of at least $60 \%$ of existing streets within the project, in addition to the use of this option on the project side of bordering streets and between the vehicle travel ways and walkways, at intervals averaging $12 \mathrm{M}$. The second is shaded streets that provide shade over at least $40 \%$ of the length of sidewalks on streets within the project (Figure. 18).
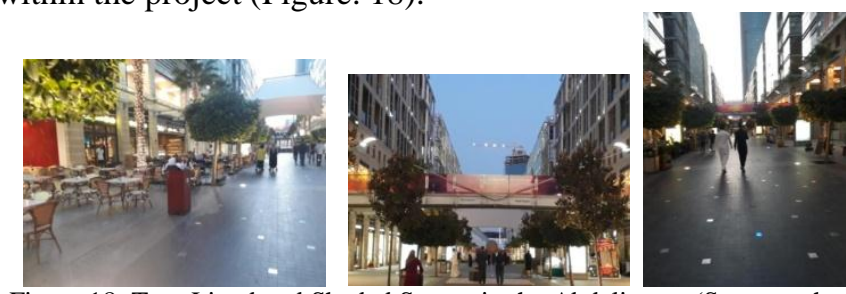

Figure 18: Tree-Lined and Shaded Streets in the Abdali area, (Sources: the researcher, 2017)

\section{Measure 2.15: Neighborhood Schools}

This measure refers to locate within walking distance to local schools.

N/A

\section{Indicator 3: Green Infrastructure and Buildings Measure 3.1: Certified Green Buildings}

This measure refers to containing at least one building certified under LEED or a similar green building rating system.

N/A

\section{Measure 3.2: Building Energy Efficiency}

This measure refers to providing superior building energy efficiency. It is noted that the project included the construction of energy-efficient buildings that reduce water, air, and land pollution and adverse environmental effects from energy consumption and production (Figure. 19). 

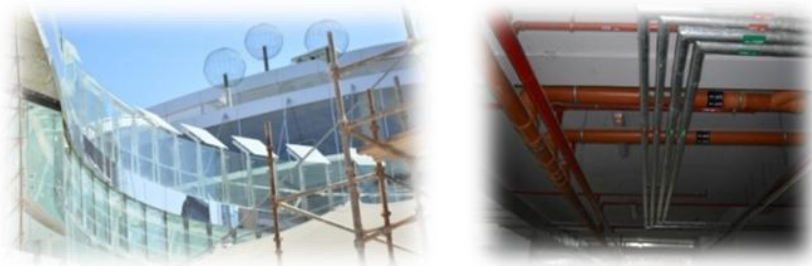

Figure 19: Building energy design in the Abdali area, (Sources: the researcher, 2017)

\section{Measure 3.3: Building Water Efficiency}

This measure refers to providing superior building water efficiency. The project encouraged sustainable water use in the operation of buildings and their sites [1]. Figure. 20 clarifies that it succeed to maximize water efficiency within buildings through identifying means of reducing potable water consumption to reduce the burden on municipal water supply and wastewater systems, therefore reducing effects on natural water resources. This was achieved by employing multi strategies like efficient toilet fixtures and grey water treatment system, which use nearly $50 \%$ less water than water use baseline calculated for the building [19].
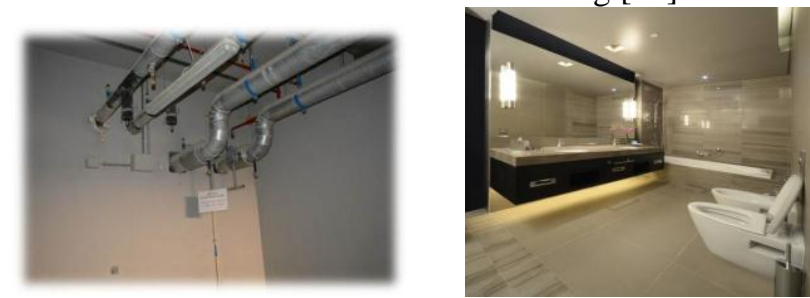

Figure 20: Water energy design in the Abdali area, (Sources, Al-abdali, 2008).

\section{Measure 3.4: Wastewater Management}

This measure refers to reuse treated wastewater.

Al-abdali project made to reduce pollution from wastewater and encouraged reusing wastewater from buildings [2]. Wastewater reuse ranges from relatively simple gray water systems that exploited non-sewer wastewater for irrigation onsite. Gray water treatment was achieved by a water circulation that is incorporated in every project within Abdali, which collects and treats gray water from showers and sinks, and re-uses it for flushing and irrigation purposes (Figure. 21).
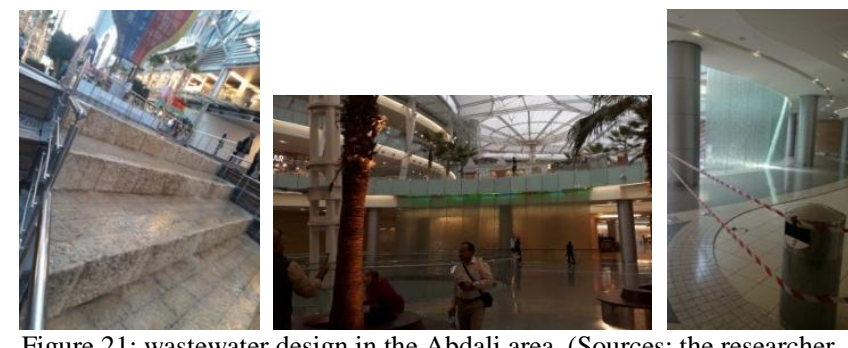

Figure 21: wastewater design in the Abdali area, (Sources: the researcher, 2017).

\section{Measure 3.5: Water-Efficient Landscaping}

This measure refers to reducing water consumption for outdoor landscaping. The project sought to limit the use of potable water and other natural surface or subsurface water resources for landscape irrigation of the project site by $50 \%$ from a calculated baseline for the site's peak watering time
(Figure. 22). Reductions were attributed to use of combination of strategies are represented in; 1) use of captured rainwater, 2) irrigation efficiency, 3) use of recycled wastewater, and 4) use of other non-potable water sources, such as air-conditioning condensate, storm water, and foundation drain water [1].
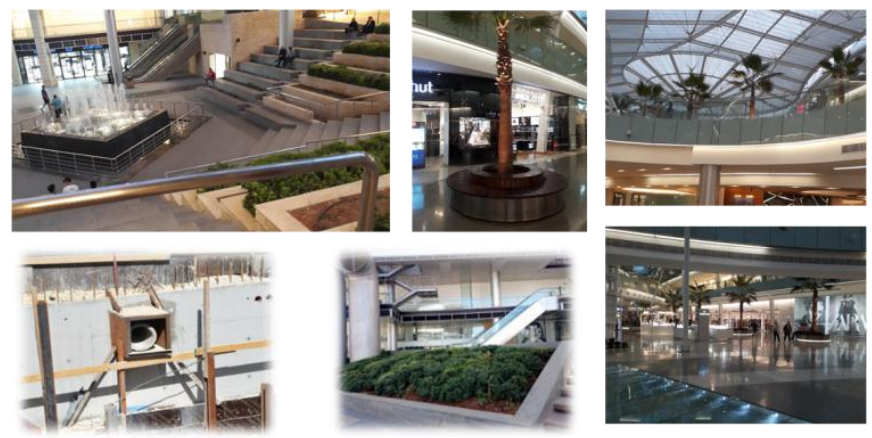

Figure 22: Water landscaping design in the Abdali area, (Sources: the researcher, 2017).

\section{Measure 3.6: Storm water Management}

This measure refers to retaining and treating storm water onsite. The project plan includes comprehensive plans for designing and implementing a storm water management system [2] [18]. The implementation of a comprehensive storm water management plan for the project that retains onsite, through infiltration or reuse. It reduced storm water pollution by keeping as much runoff as possible from flowing off the site and filtering and reabsorbing storm water runoff naturally, using multi techniques like use of street-side "swales" (low-lying, and often marshy areas), green roofs, and storm water retention basins (Figure. 23).
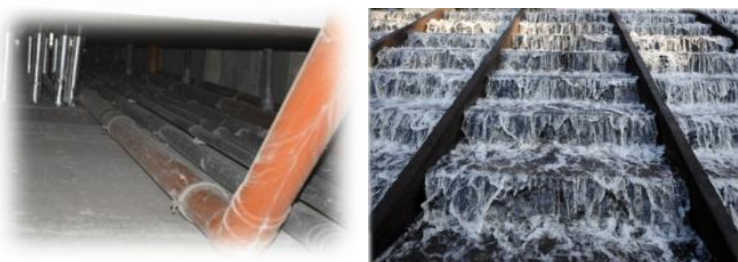

Figure 23: Storm water design in the Abdali area, (Sources: Al-abdali, 2008).

Measure 3.7: Existing Building Use

This measure refers to reuse existing buildings. N/A

Measure 3.8: Historic Resource Preservation and Adaptive Use

This measure refers to reuse and restore historic buildings. N/A

Measure 3.9: Minimized Site Disturbance in Design and Construction

This measure refers to preserving heritage trees and previously undeveloped land.

N/A

\section{Measure 3.10: Heat Island Reduction}

This measure refers to use roofing and paving that reflects instead of absorbs solar heat. The project used a wide range of mechanisms to reduce absorption of solar heat, are 
represented in providing shade from open structures, such as canopied walkways and solar photovoltaic panels, and using high-reflectance and vegetated roofs of new buildings within the project at least $50 \%$ of the buildings roofs (Figure. 24).
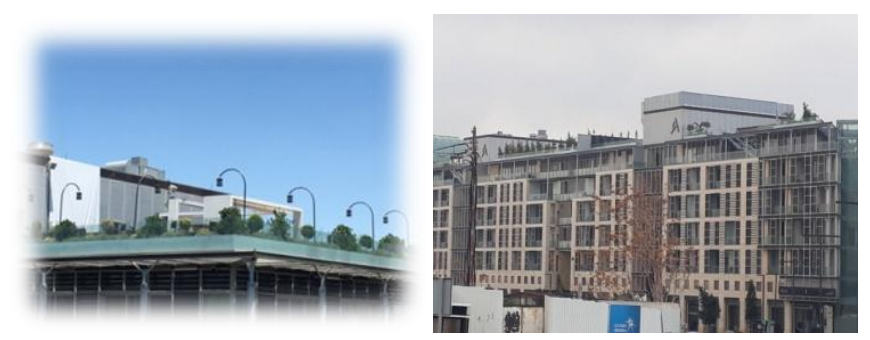

Figure 24: Roof gardens in the Abdali area, (Sources: the researcher, 2017).

\section{Measure 3.11: Solar Orientation}

This measure refers to increasing passive and solar access by orienting buildings or dense blocks to maximize north- and south facing exposure. To encourage energy efficiency, it is noted that the Al-abdali area tried to create optimum conditions for using passive and active solar strategies. These strategies could be summarized in; the project was located on existing blocks which was oriented at least $75 \%$ of the blocks have one axis within plus or minus 15 degrees of geographical east-west (Figure. 25).

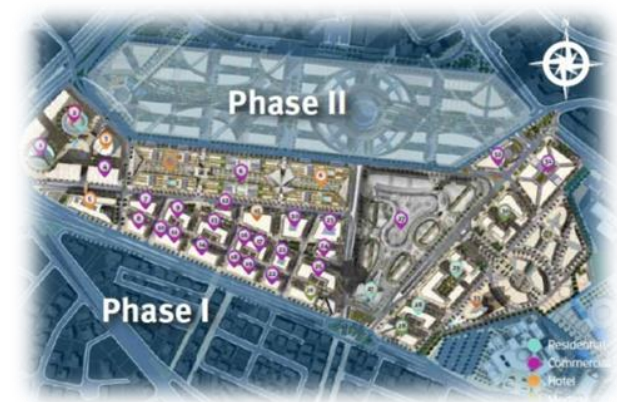

Figure 25: Abdali plan, (Sources: GAM, 2017). Modified by the researcher

\section{Measure 3.12: Light Pollution Reduction}

This measure refers to the limitation of exterior illumination and direct it downward. Multi strategies for reducing light pollution were used by the buildings of project to increase night sky access and improve night-time visibility [18]. These strategies could be included directing artificial light downward instead of upward and outward, in addition to using more frequently spaced, lower intensity lights instead of only a few very bright lights (Figure. 26).
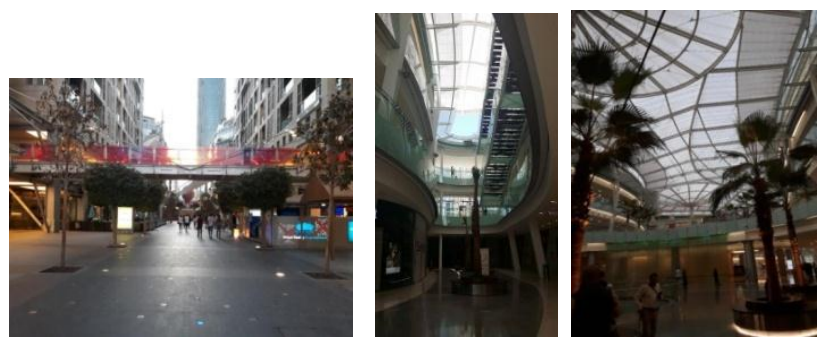

Figure 26: Light design in the Abdali area, (Sources: the researcher, 2017).

\section{Measure 3.13: District Heating and Cooling}

This measure refers to providing building heating and cooling through a shared neighborhood-wide system.

For the encouragement of the development of energyefficient neighbourhood, the buildings employed district heating and cooling strategies at neighbourhood level to reduce energy use and adverse energy-related environmental effects (Figure. 27).

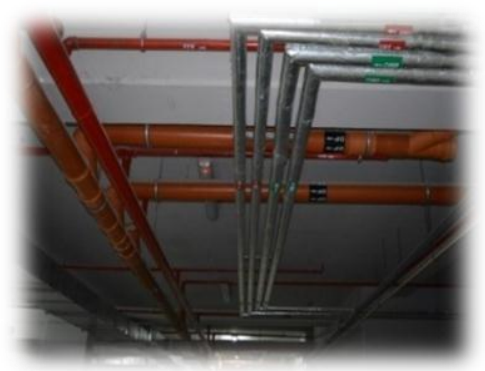

Figure 27: Heating and Cooling system, (Sources: the researcher, 2017).

\section{Measure 3.14: Infrastructure Energy Efficiency}

This measure refers to providing energy-efficient neighbourhood infrastructure. The project tried to limit adverse environmental effects from energy used for operating infrastructure [18]. This was achieved through working with the municipality to design and implement all of new infrastructure, including but not limited to street lights, and water and wastewater pumps, therefore achieving a $15 \%$ annual energy reduction below an estimated baseline energy use for the infrastructure of this project (Figure.28).
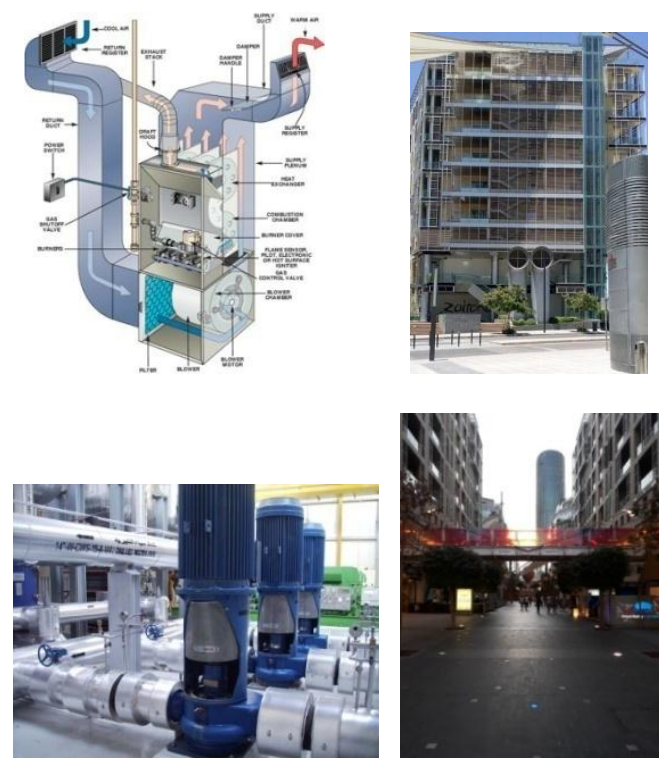

Figure 28: infrastructure energy system within the Abdali area, (Sources: GAM, 2017). Modified by the researcher

\section{Measure 3.15: On-Site Renewable Energy Sources}

This measure refers to generating renewable energy on-site. The project encouraged on-site renewable energy production to limit the adverse environmental and economic effects associated with fossil fuel energy use [2]. It is noted that the Greater Amman Municipality worked to develop on-site 
renewable energy generation systems and technologies like Wind Geothermal small scale/ to meet the main needs of the project (Figure. 29). In addition, park lights, water pumps, sewer systems and light-emitting diode (LED) technology for traffic also significantly minimized a neighbourhood's total level of energy consumption.
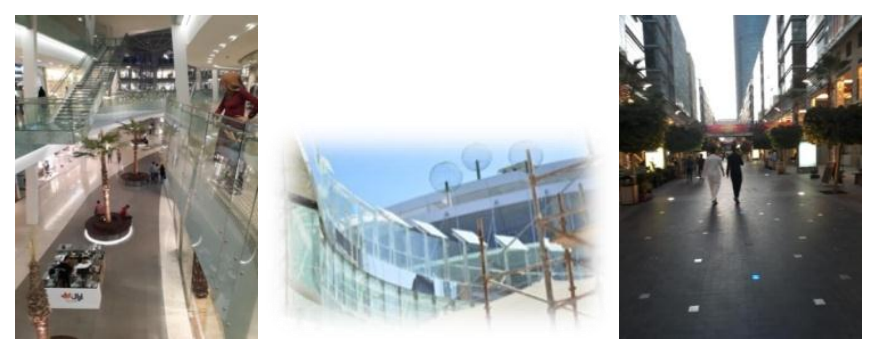

Figure 29: Renewable energy system in the Abdali area, (Sources: the researcher, 2017)

\section{Indicator 4: Innovation and Design Process}

Measure 4.1: Innovation and Exemplary Performance

This measure refers to the exhibition of exemplary environmental performance in areas not addressed by the LEED-ND rating system. The project has used multi mechanisms to increase exemplary environmental performance in the area as shown in Figure. 30.
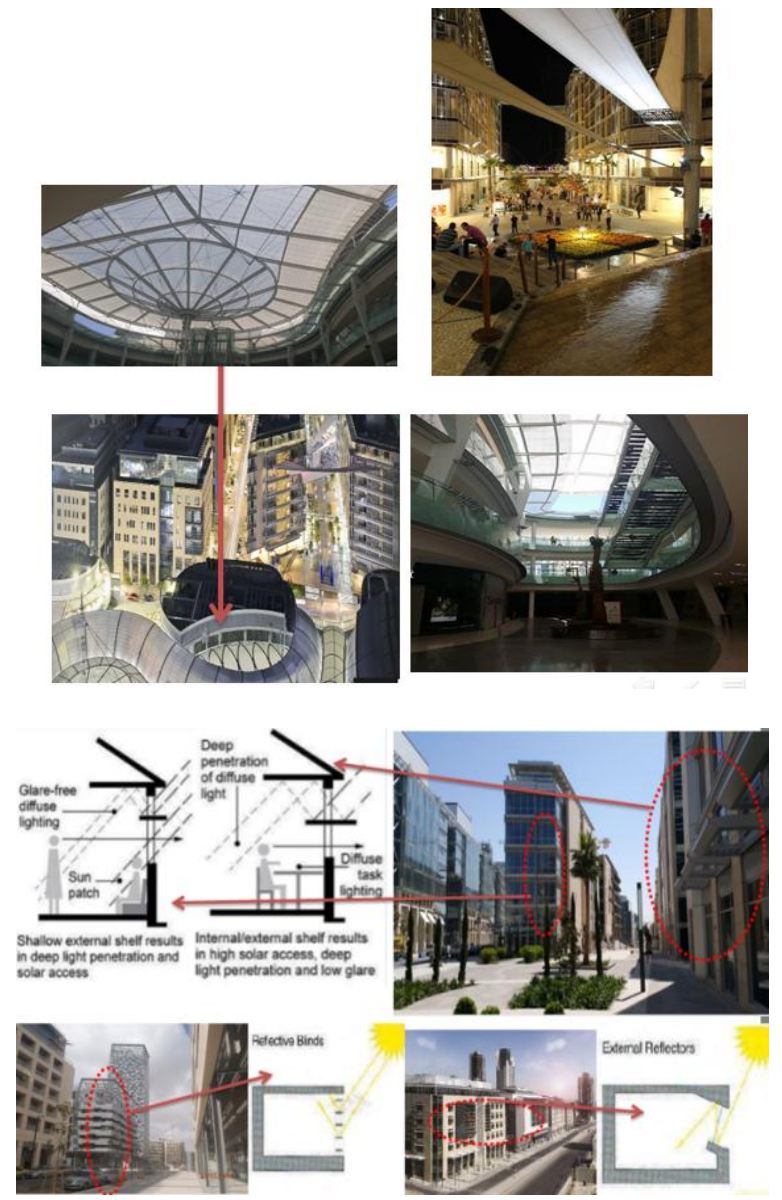

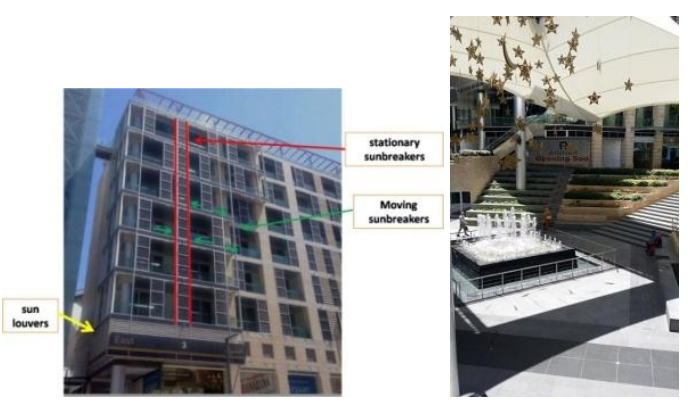

Figure 30: Innovation mechanisms in the Abdali area, (Sources: the researcher, 2017).

Measure 4.2: LEED Accredited Professional

This measure refers to having a team member that is: a LEED Accredited Professional, and credentialed in smart growth by the Natural Resources Defense Council and Smart Growth America, or credentialed in new urbanism by the Congress for the New Urbanism. N/A

Measure 3.16: Recycled Content in Infrastructure

This measure refers to the use of recycled content in neighbourhood infrastructure.

N/A

Measure 3.17: Solid Waste Management Infrastructure

This measure refers to providing neighbourhood composting, recycling, and hazardous waste collection.

N/A

\section{Indicator 5: Regional Priority \\ Measure 5.1: Regional Priority}

This measure refers to addressing geographically specific environmental, social equity, or public health priorities. The Abdali area has geographically addressed environmental, social, and public health priorities through the application of urban sustainability indicators covering three dimensions; social, environmental and economic [1] [19]. This application provided a set of solutions to the main issues to overcome the main constraints facing the construction of this project.

\section{DISCUSSION}

This section presented an analytical study of the Al-abdali area in Amman, Jordan. The testing of the theoretical urban sustainability indicators in the context of this areas is summarised in Table 3. The compliance analysis is used by this study, which consists of two types as represented by the included indicators (met threshold, denoted by *) and the not included indicators (did not meet threshold, denoted by $\mathrm{O}$ ). 
International Journal of Applied Engineering Research ISSN 0973-4562 Volume 13, Number 19 (2018) pp. 14345-14358

(C) Research India Publications. https://dx.doi.org/10.37622/IJAER/13.19.2018.14345-14358

Table 3: The comparison between the three selected areas (A, B, C) in Amman

\begin{tabular}{|c|c|c|c|}
\hline \multirow{3}{*}{ indicators } & \multirow{3}{*}{ measurements } & & \\
\hline & & \multicolumn{2}{|c|}{ Results } \\
\hline & & & Points \\
\hline \multirow{10}{*}{$\begin{array}{l}\text { Smart Location and } \\
\text { Linkage }\end{array}$} & preferred Locations & * & 5 \\
\hline & Brown fields Redevelopment & * & 1.5 \\
\hline & $\begin{array}{l}\text { Locations with Reduced Automobile } \\
\text { Dependence }\end{array}$ & $*$ & 4 \\
\hline & Bicycle Network and Storage & $*$ & 1 \\
\hline & Housing and Jobs Proximity & $*$ & 2 \\
\hline & Steep Slope Protection & $\mathrm{O}$ & 0 \\
\hline & $\begin{array}{l}\text { Site Design for Habitat or Wetland and Water } \\
\text { Body Conservation }\end{array}$ & $\mathrm{O}$ & 0 \\
\hline & $\begin{array}{l}\text { Restoration of Habitat or Wetlands and Water } \\
\text { Bodies }\end{array}$ & $\mathrm{O}$ & 0 \\
\hline & $\begin{array}{l}\text { Long-Term Conservation Management of } \\
\text { Habitat or Wetlands and Water Bodies }\end{array}$ & $\mathrm{O}$ & 0 \\
\hline & & & 13.5 \\
\hline \multirow{16}{*}{$\begin{array}{l}\text { Neighborhood } \\
\text { Pattern and Design }\end{array}$} & Walk able Streets & $*$ & 6 \\
\hline & Compact Development & * & 3.5 \\
\hline & Mixed-Use Neighborhood Centers & $*$ & 2.5 \\
\hline & Mixed-Income Diverse Communities & $\mathrm{O}$ & 0 \\
\hline & Reduced Parking Footprint. & $*$ & 1 \\
\hline & Street Network & $*$ & 1.5 \\
\hline & Transit Facilities & $*$ & 1 \\
\hline & Transportation Demand Management & $\mathrm{O}$ & 0 \\
\hline & Access to Civic and Public Space & * & 1 \\
\hline & Access to Recreation Facilities & $*$ & 1 \\
\hline & Visit ability and Universal Design & $*$ & 1 \\
\hline & Community Outreach and Involvement & * & 1.5 \\
\hline & Local Food Production & $\mathrm{O}$ & 0 \\
\hline & Tree-Lined and Shaded Streets & $*$ & 1.5 \\
\hline & Neighborhood Schools & $\mathrm{O}$ & 0 \\
\hline & & & 20.5 \\
\hline \multirow{18}{*}{$\begin{array}{l}\text { Green } \\
\text { Infrastructure and } \\
\text { Buildings }\end{array}$} & Certified Green Buildings & $\mathrm{O}$ & 0 \\
\hline & Building Energy Efficiency & $*$ & 1.5 \\
\hline & Building Water Efficiency & $*$ & 1 \\
\hline & Water-Efficient Landscaping & $*$ & 1 \\
\hline & Existing Building Reuse & $\mathrm{O}$ & 0 \\
\hline & $\begin{array}{l}\text { Historic Resource Preservation and Adaptive } \\
\text { Use }\end{array}$ & $\mathrm{O}$ & 0 \\
\hline & $\begin{array}{l}\text { Minimized Site Disturbance in Design and } \\
\text { Construction }\end{array}$ & $\mathrm{O}$ & 0 \\
\hline & Storm water Management & $*$ & 2.5 \\
\hline & Heat Island Reduction & $*$ & 1 \\
\hline & Solar Orientation & $*$ & 1 \\
\hline & On-Site Renewable Energy Sources & $*$ & 2 \\
\hline & District Heating and Cooling & $*$ & 1.5 \\
\hline & Infrastructure Energy Efficiency & $*$ & 1 \\
\hline & Wastewater Management & $*$ & 1.5 \\
\hline & Recycled Content in Infrastructure & $\mathrm{O}$ & 0 \\
\hline & Solid Waste Management Infrastructure & $\mathrm{O}$ & 0 \\
\hline & Light Pollution Reduction & $*$ & 1 \\
\hline & & & 15 \\
\hline \multirow{3}{*}{$\begin{array}{l}\text { Innovation and } \\
\text { Design Process }\end{array}$} & Innovation and Exemplary Performance & $*$ & 3 \\
\hline & LEED Accredited Professional & $\mathrm{O}$ & $\mathrm{O}$ \\
\hline & & & 4 \\
\hline \multirow[t]{2}{*}{ Regional Priority } & Regional Priority & & 2.5 \\
\hline & & & 2.5 \\
\hline Total & 54.5 & & \\
\hline
\end{tabular}

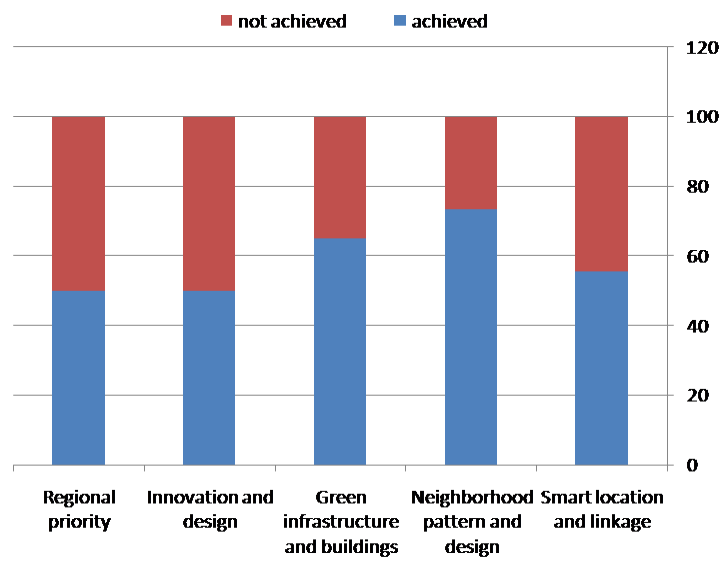

Figure 31: The percentage of application of urban sustainability indicators

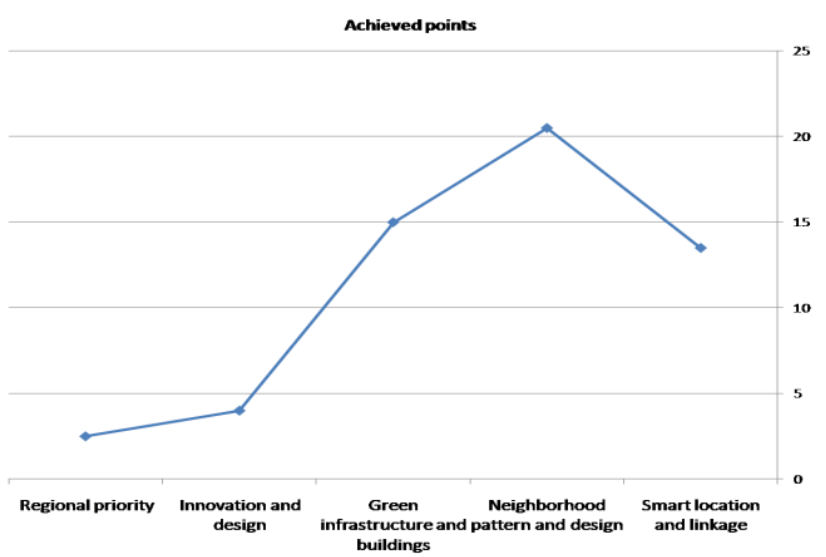

Figure 32: Compliance with the 5 indicators

Figure 31 shows the sustainable urban indicators results that were applied at the neighbourhood level of the Abdali area. It confirms that neighbourhood pattern and design indicator represent the highest percentage of urban sustainability indicators, where 11 of 15 are included measurements. Therefore, it is identified as the most suitable indicator for this area and is, therefore, can be used to develop the surrounding areas within Amman Master Plan. As for the lowest percentage of these indicators, they are represented in innovation and design and regional priority indicators, therefore are considered the least favourable indicators to be applied to the Abdali area.

A priority was given for the neighbourhood pattern and design indicator in the Abdali master plan. It was also found that this indicator have positively influenced the Abdali area, through the increase of the percentage of its successful measurements (Figure 32). In addition, the Green infrastructure and buildings and smart location and linkage indicators implemented in the Abdali master plan have contributed to improvements to the Amman master plan which in turn positively serves the local community and investors.

According to the indicators test, the research identified the suitable indicators and their ranking for the Abdali area based on their measurements which met the threshold as shown in Table 4 below. 
Table 4 : The suitable indicators and their measurements for the Abdali area

\begin{tabular}{|c|c|c|}
\hline & indicators & measurements \\
\hline \multirow[t]{11}{*}{ 1) } & \multirow{11}{*}{$\begin{array}{l}\text { Neighborhood } \\
\text { Pattern and Design }\end{array}$} & Walk able Streets \\
\hline & & Compact Development \\
\hline & & Mixed-Use Neighborhood Centers \\
\hline & & Reduced Parking Footprint \\
\hline & & Street Network \\
\hline & & Transit Facilities \\
\hline & & Access to Civic and Public Space \\
\hline & & Access to Recreation Facilities \\
\hline & & Visit ability and Universal Design \\
\hline & & Community Outreach and Involvement \\
\hline & & Tree-Lined and Shaded Streets \\
\hline \multirow[t]{11}{*}{ 2) } & \multirow{11}{*}{$\begin{array}{l}\text { Green } \\
\text { Infrastructure and } \\
\text { Buildings }\end{array}$} & Building Energy Efficiency \\
\hline & & Building Water Efficiency \\
\hline & & Water-Efficient Landscaping \\
\hline & & Storm water Management \\
\hline & & Heat Island Reduction \\
\hline & & Solar Orientation \\
\hline & & On-Site Renewable Energy Sources \\
\hline & & District Heating and Cooling \\
\hline & & Infrastructure Energy Efficiency \\
\hline & & Wastewater Management \\
\hline & & Light Pollution Reduction \\
\hline \multirow[t]{5}{*}{ 3) } & \multirow{5}{*}{$\begin{array}{l}\text { Smart Location } \\
\text { and Linkage }\end{array}$} & preferred Locations \\
\hline & & Brown fields Redevelopment \\
\hline & & $\begin{array}{l}\text { Locations with Reduced Automobile } \\
\text { Dependence }\end{array}$ \\
\hline & & Bicycle Network and Storage \\
\hline & & Housing and Jobs Proximity \\
\hline \multirow[t]{2}{*}{ 4) } & \multirow{2}{*}{$\begin{array}{l}\text { Innovation and } \\
\text { Design Process }\end{array}$} & Innovation and Exemplary Performance \\
\hline & & LEED Accredited Professional \\
\hline 5) & Regional Priority & Regional Priority \\
\hline
\end{tabular}

\section{CONCLUSIONS AND RECOMMENDATIONS}

The study enhanced the knowledge level required for the implementation of sustainable urban design principles at the neighbourhood level. This was achieved by introducing a framework focusing on the key suitable indicators for the implementation of sustainable urban design principles in Amman, which can be used effectively and further fine-tuned to reflect place specific variables. This research identified a broad variety of suitable indicators and their ranking for the Abdali area, which can be implemented is: (1) Neighbourhood Pattern and Design (2) Green Infrastructure and Buildings (3) Smart Location and Linkage (4) Innovation and Design Process (5) Regional Priority. Hence, this ranking represents the priority for implementing these indicators in the Abdali master plan, enhancing the effective implementation of the sustainable urban design principles in Amman.

This research recommends to develop the guidelines responsible for the Abdali master plan based on the suitable indicators identified by this study as clarified in Table 4. Moreover, it takes into account the ranking of these suitable indicators for the purpose of prioritising their implementation in the Amman master plan. This ranking provides a feedback which identifies the main priorities to each principle to overcome the constraints facing the construction of sustainable neighbourhood in the Amman master plan. This will help to implement and manage sustainable urban design principles at the neighbourhood level in the Amman context. This knowledge therefore provides an opportunity to the city of Amman for informing the future development of the master plan.

\section{Reflections}

The focus on a single case study was decided in order to understand and realize the complexity and uniqueness of the individual case. Researchers such as Yin [50] considered the limitations of the single case study strategy in that it could only reflect the uniqueness, or special conditions, that apply to the case study in question. Whilst recognising this, Researchers such as Bennett [8], Tunnard and Wilson [45] and Flyvbjerg [17], state that one can generalise on the basis of a single case as supplementary to scientific development. The knowledge therefore can enter into the collective process of knowledge accumulation in a given field [6]. Ettlinger [14] stated that a single case study strategy can offer valuable insight into a "set of possibilities that may become scaled up". Therefore, this study presents valuable insight into the relationship between the physical environment, sustainability and locational elements that can in turn impact on the sustainability performance of a neighbourhood, which can be scaled up in the future.

\section{ACKNOWLEDGEMENT}

The generous funding of the Department of ARchitecture at the Al al-Bayt University from 2017 to 2018 is gratefully acknowledged. The GIS Department of the Greater Irbid Municipality kindly provided data on the urban development of the city of Irbid.

\section{REFERENCES}

1) Abdali. (2004). Abdali: The New Downtown of Amman. Amman: Abdali Investment \& Development PSC.

2) Abdali. 2008. Abdali; Facts and figures. http://www.abdali.jo/index.php?r=site/page \&id=6, 208-2017).

3) AlWaer, H., and Simbley, M. (2006): Sustainable Development for Regional Shopping Centres in the UK: Measuring the Level of Sustainability and Application of a Sustainability Assessment Model /SCRSC/. International conference on urbanism and sustainability in a changing world. Jeddah urban forum.

4) Ayyoob, A., and Akito, M. (2013b): "A critical review of seven selected neighborhood sustainability assessment tools". Environmental Impact Assessment Review 38.doi:10.1016/j.eiar.2012.06.006.

5) Ayyoob, S., and Akito, M. (2014): "Viability of using global standards for neighbourhood sustainability assessment: insights from a comparative case study". Journal of Environmental Planning and Management: 1-23. doi:10.1080/09640568.2013.866077.

6) Basaiawmoit, R., and Wanger, K. (2015): AutoEthnographic perspective of social entrepreneurship focused student case-competition. The proceedings of 3rd International Conference on Innovation and Entrepreneurship (ICIE). The university of Kwazulu Natal Durban.

7) Baslas, C. (2004): Measuring the liveability of an urban center: An exploratory study of key performance indicators, Planning practise and 
research, 19 (1). 101-110.

8) Bennett, A., and Elman, C. (2006): Qualitative research: Recent developments in case study methods. Annual Review of Political Science, 9(1), 455-476.

9) Brandon, S., and Lombardi, P. ( 2011): Evaluating Sustainable Development in the Built Environment. II Edition, Wiley-Blackwell (GBR), pp. 272, ISBN: 9781405192583; REFERENCE PROFESSOR(S)Patrizia Lombardi

10) BREEAM Communities. (2012): Integrating sustainable design into master planning. Available online at [www.breeam.org/ communities].

11) Cocca, P., and Alberti, M. (2010): A framework to assess Performance Measurement Systems in SMEs, International Journal of Productivity and Performance Management, Special Issue "Performance measurement and management: what is next?", Vol. 59, No. 2, pp.186-200, ISSN 1741-0401

12) Deeb, R., Mhana, S. (2009): Planning for sustainable development. Journal of engineering science, Damascus University.

13) Estidama. (2010): Pearl Community Rating System (PBCS): Design and Construction, Version 1.0. Abu Dhabi Urban Planning Council

14) Ettlinger, N. 2009. Problematizing the presentation of post-structural case-study research, or working out the crisis of representation in the presentation of empirics," Environment and Planning A 41: 10171019.

15) European Commission, Eurostat (2009a): Indicators for Monitoring the EU Sustainable Development Strategy.

http://epp.eurostat.ec.europa.eu/portal/page/portal/sdi/i ntroduction.

16) Farr, D. (2007): Sustainable Urbanism: urban design with nature. New York: John Wiley.

17) Flyvbjerg, B. (2006): "Five Misunderstandings About Case-Study Research," Qualitative Inquiry, vol. 12, no. 2, April 2006, pp. 219-245.

18) GAM. (2007). Interim Growth Strategy (HDMU) Development Manual. Amman: Greater Amman Municipality.

19) GAM. (2008). The Amman plan: Metropolitan Growth. Amman: Greater Amman Municipality.

20) Green Star Team. (2012): Green Star System. Green Building Council of Australia. Available online at [https://www.gbca.org.au/green-star/]

21) Gulf Organization for Research and Development institute (GORD). (2014): Global Sustainability Assessment System (GSAS), Qatar Sustainability Assessment System (QSAS). Available online at [http://www.gord.qa/uploads/formsnew/GSAS_Overvi ew_07_for_web.pdf]

22) Haapio, A., and Viitaniemi, P. (2007): Environmental criteria and indicators used in environmental assessment of buildings. Proceedings, CIB World Congress, Construction for Development, 14-7 May; 2007. Cape Town, South Africa.

23) Haapio, A. (2012): Towards sustainable urban communities. Environmental Impact Assessment
Review. 32 (2012) 165-169.

24) Khawaja, H. 2015. Public Spaces under Threat: Scenes from Amman. Research Master Planning and Sustainability: Urban and Regional Planning. Polytech university tour. France

25) LEED. (2009a): LEED for Neighborhood Development Rating System. Created by the Congress for the New Urbanism, Natural Resources Defense Council, and the U.S. Green Building Council. (Updated May 2011)

26) LEED. (2009b): LEED for New Construction and Major Renovations Rating System With Alternative Compliance Paths For Projects Outside the U.S., U.S. Green Building Council, Washington DC.

27) LEED. (2011): LEED 2009 for New Construction and Major Renovations Rating System With Alternative Compliance Paths For Projects Outside the U.S. (Updated November 2011) U.S. Green Building Council, Washington DC.

28) Martien, K., and Taylor, B. (2003): Limitations of hypothesis-testing in defining management units for continuously distributed species. J. Cetacean res. manage. 5(3):213-218.

29) McGeough, U., Newman, D., Wrobel, J. (2004): Model for Sustainable Urban Design. Sustainable Energy Planning Office (ORNL), Gas Technology Institute (GTI)

30) McIntyre, P. (2004): Creativity and Cultural Production: A Study of Contemporary

31) McIntyre, P. (2006): Creative Practice as Research: 'Testing Out' the Systems Model of Creativity through Practitioner Based Enquiry. Speculation and Innovation: applying practice led research in the Creative Industries. School of Design, Communication and Information Technology. University of Newcastle. Working paper.

32) Miller, T. (2002): Living in the Environment: Principles, connections and solutions, 12th edition, Thomson Learning, Inc: New York.

33) Ndeke, E. (2011): A critical review of the development of sustainability indicators for the City of Cape Town: A focus on environmental and socioeconomic sustainability. Thesis presented in fulfilment of the requirements for the degree of Master of Philosophy in Sustainable Development Planning and Management in the Faculty of Economic and Management Sciences at Stellenbosch University.

34) Neuman, M. (2005): "The Compact City Fallacy." Journal of Planning Education and Research. Vol. 25. pp. 11-26.

35) Potter R., Darmame K., Barhamb N. \& Nortcliff S. (2009). "Ever-growing Amman', Jordan: Urban expansion, social polarisation and contemporary urban planning issues. Habitat International 33, 81-92.

36) Reed, R., Bilos, A., Wilkinson, S. and Schulte, K. (2011): "International Comparison of Sustainable Rating Tools", American Real Estate Society American Real Estate Society, vol. 1, no. Number 1 / 2009, pp. 1-22.

37) Rowan, L. (2002): Sustainable Development 
Indicators and Local Government. Thesis submitted for the degree of Doctor of Philosophy. Department of Management and Organisation. University of Stirling

38) Runco, M., and Pritzker, S. (Eds.) (1999): Encyclopedia of Creativity. San Diego, Calif., Academic Press.

39) Salat, S., Bourdic, L., and Nowacki, C. (2012): Assessing cities: A new system of spatial indicators. Building Research and Information Volume 40, Issue 5, 2012. Special Issue: Spatial and temporal scales in sustainability: SB11

40) Scipioni, A., Mazzi, A., Mason, M., Manzardo, A. (2009): "The Dashboard of sustainability to measure local urban sustainable development. The case study of Padua Municipality". Ecological Indicators. Vol. 9: pp 364-380.

41) Sharifi, A., and Murayama, A. (2014): Neighborhood sustainability assessment in action: Cross-evaluation of three assessment systems and their cases from the US, the UK, and Japan. Building and Environment, 72, 243-258.

42) Shen,L., Ochoa,J., Shah,M., Zhang,X. (2011): The application of urban sustainability indicators e A comparison between various practices. Habitat International, 35 (2011), P. 17-29

43) Stockburger, D. (2007): "Hypothesis and hypothesis testing", Encyclopedia of Measurement and Statistics (editor-Salkind N.J.), Sage Publications.

44) Thomas, R., and Ferdham, M. (2003): Sustainable urban design - an environmental approach, Taylor and Francis, 2003.

45) Tunnard, C., and Wilson, B. (2014): Comparison of neuropsychological rehabilitation techniques for unilateral neglect: an ABACADAEAF single-case experimental design. Neuropsychol Rehabil. 2014;24(3-4):382-99. doi: 10.1080/09602011.2013.872041. Epub 2014 Jan 13.

46) United Nations, Commission on Sustainable Development (CSD). (2007a): Indicators of sustainable development: Guidelines and methodologies; International Urban Sustainability Indicators List (IUSIL), New York

47) William, M. (1982): Concept Testing. Journal of Business Research 10, 279-294

48) Xing, Y., Horner, R., El-haram, M., Bebbington, J. (2009): A framework model for assessing sustainability impacts of urban develpment. Accounting forum. 33, 209-224.

49) Ziod, R. (2012). The Development of Commercial districts in Amman 1950-2009. Amman: Greater Amman Municipality- Cultural Department.

50) Yin, R. (2009): Case study Research: design and methods. 4th edition. London: Sage. 